\title{
(Re)Translating as Re-membering
}

\author{
Julie Tarif \\ University of Alberta, Canada \\ Prismes, EA 4398, Sorbonne Nouvelle, France
}

Literature, and translation therefore, seem to be inextricably linked to the image of the body. This is visible in the metaphorical associations of both text and body on two different levels: on the intertextual level, it is not uncommon to speak of "the body of literature" or of "a corpus of texts"; on the intratextual level, of "the body of a text". Furthermore, the literary canon is seen as "the literary work of memory" (Bloom 17). Hence the choice here to explore the notion of "remembering" as a notion both linked to the body and to the memory, an integral part of the body. The purpose of this article is to explore how (re)translation, in the large sense of the term - that is as both interlingual and intersemiotic translation, in Jakobsonian terminology (Jakobson 114) — can be perceived as a way of both remembering and re-membering ${ }^{1}$. In other words, how can (re)translation proper and adaptations of a work-Charles Dickens' Oliver Twist being the work selected to lead this study-be seen as a way of not forgetting the literary legacy of other cultures but also as a way of re-generating the body of literature of the translating culture? In particular, this paper investigates how the regeneration and reshaping of the French literary body, in which those works play a crucial part, takes place through (re)translation. It does so by interrogating the different forms (re)translation can take, the frequency of the phenomenon and the targeted readership.

This study is therefore grounded in the metaphorical vision of literature as an organic living body, growing and evolving, with translation playing a vital part in regenerating it. In so doing, it draws on the vision of literature as a dynamic and heterogeneous system, in the tradition of EvenZohar' polysystem theory (9-26). Even-Zohar's theory takes into account the intrasystemic relations (relations within the literary system) that can lead to changes within the literary system. One significant aspect of his theory used in the course of this study is the concept of a centre and a periphery shaping the literary polysystem. The centre is associated with the idea of "canonized texts" and the periphery, with "non-canonized texts" (Even-Zohar 15-17). In a more holistic vision, as proposed in this article, Even-Zohar's approach can be applied to other cultural phenomena that also form a system of their own. Literature as a system coexists and interacts with other systems within the general cultural system as a whole. In this respect, when investigating literary changes, both intrasystemic and intersystemic relations are of interest.

A systemic approach to translation studies, as developed by Even-Zohar, Toury and Lefevere, will provide the theoretical framework for this analysis. In this approach, translated literature is a sub-system within the target literature system. This approach focuses on the integration

\footnotetext{
1 The words "re(-)membering" or "re(-)memberment" are used further down in the introduction as a more concise way to refer to the combined notions of "remembering and re-membering".

2 Toury distinguished between two types of norms that he calls preliminary and operational norms. Preliminary norms govern among other things the type of text to be imported in a particular culture, and operational norms the translator's
} This work is licensed under a Creative Commons Attribution 3.0 License 
of a work in the target culture, taking into account the interliterary links between cultures, along with the intraliterary connections within a given cultural system. Translated literature is conceived as "an integral system within any literary polysystem" and "as a most active system within it" (Even-Zohar 46). As such, translation participates in shaping and regenerating the polysystem, or what is also called here "re-memberment", as a variation on the notion of "re-membering". But this is not a one way relationship: translation is also in turn shaped by the polysystem, what is thus referred to as "dis-memberment". Both "dis-memberment" and "re-memberment" therefore tie in with the idea of a translated text viewed as a textual body. "Re-memberment", furthermore, conjures up the idea of "memory" and of "remembering" the source text. In other words, "dis-memberment" implies taking liberties with the source text and a certain dilution of the original text as a consequence. On the contrary, "re-memberment" suggests the preservation of the integrity of the source text and a greater adequacy or accuracy to the source text.

In other words, the position assumed by translated literature in the polysystem is either central or peripheral and has consequences on the translation process. That was the starting point of Toury's in-depth analysis of the nature and role of norms ${ }^{2}$ during the translating act, norms that the present article relies on, as well as on Lefevere's systemic approach. Lefevere similarly concentrated on the constraints imposed on the production of literary texts, but his approach incorporates other cultural images of the literary work. It goes beyond the interligual translation(s) of a work to incorporate all its different "rewritings" 3 . His research opens the analysis of the literary evolution and production to intracultural connections, giving a more comprehensive and accurate picture of the interactions between different systems within one cultural system.

The present work also subscribes to the idea of a dependence between "retranslation as re(-)membering" and canonicity. This is not to say that "retranslation as re(-)membering" is not valid for genres positioned on the margin of the literary canon such as experimental writing. Those texts can in their turn achieve canonicity and be remembered as "classics" through (re)translation. This complex relationship is highlighted by Venuti: on the one hand, retranslation helps a work achieve canonicity: "A foreign text that is positioned on the margin of the literary canons in the translating language may be retranslated in a bid to achieve canonicity through the inscription of a different interpretation" (Venuti 27, my emphasis); and on the other hand, canonicity calls for retranslation:

The sheer cultural authority of this text [a foreign text that has achieved canonical status in the translating culture] [...] is likely to solicit retranslation because diverse domestic readerships will seek to interpret it according to their own values and hence develop

\footnotetext{
2 Toury distinguished between two types of norms that he calls preliminary and operational norms. Preliminary norms govern among other things the type of text to be imported in a particular culture, and operational norms the translator's decisions during the translation process (58).

3 The term "rewriting" was used by Lefevere to refer to "such operations as translation, criticism, reviewing, summary, adaptation for children, anthologizing, making into a comic strip or TV film, and so on, in short any processing of a text, whether in the same or another language or in another medium" (Hermans 127).
} 
different retranslation strategies that inscribe competing interpretations. (Venuti 25-26, my emphasis)

The cases presented here have, however, already achieved cultural authority and are therefore called "classics". The action of "remembering" is central to that very notion since a classic is defined as "a work of enduring value" (Mukherjee 1027) or "a work of art which will transcend time" (Ezell 3).

In the process of achieving cultural authority and defying time a text knows several modes of expression that are captured under the general notion of "rewritings" by Lefevere. To put it in Lefeverian terms, this article concentrates on two particular types of rewritings since it investigates the interlingual and the intersemiotic translations of a classic. It also borrows from Grossman's tripartite taxonomy, as the latter acknowledges an operation beyond the literary per se that is absent from Lefevere's terminology but that is significant when investigating the making of a classic: "commodification". " Grossman makes a distinction between what she calls "mimesis" or "representation", "extrapolation" and "commodification": "[r]epresentation involves works of art that adhere more or less to the original; extrapolation permits creative enterprises only loosely connected to the text ${ }^{5}$; and commodification designates the strictly commercial exploitation of cultural properties" (489). "Mimesis" is thus on the side of what is called in this article "re(-)memberment" and both "extrapolation" and "commodification", the two notions that are exploited here, are on the side of "dis-memberment". In the light of those notions of "rememberment" and "dis-memberment", the article examines different renderings of a source text on its way to canonicity, ranging from its rewritings through translation and adaptation to its commodification. This progress is represented as the "journey and metamorphoses" of a classic.

As announced earlier on in the introduction, the analysis is narrowed down to the journey and metamorphoses of one nineteenth-century English classic in France, Charles Dickens' Oliver Twist. This particular work has been selected on account of its success in France, as testified by the numerous editions of the work in translation and its many adaptations, a list of which is provided in the appendix. Four interlingual translations of Oliver Twist have been retained in the corpus due to their "memorability" in the target culture. This memorability translates into their "visibility" on the French literary market ${ }^{6}$. These translations are currently the ones available in libraries or bookshops in France; they are also the translations of the source text that are available as e-books on the

\footnotetext{
${ }^{4}$ Grossman's analysis intersects with Lefevere's as she also focuses on other images of the source text in different media. Yet, her perspective is slightly different from Lefevere's in that, despite her focus on "commodification", she is mostly interested in cinematographic and musical adaptations of the original and she establishes a classification that relies on the liberties taken with the source text rather than the media at stake in the process.

${ }^{5}$ Grossman gives the example of a character who "is plucked from his or her literary context and placed in a new situation [...]" (Grossman 489)

${ }^{6}$ Jeanne Dulong's translation (1948), along with Madeleine Bouygues's (1953) are not included into the corpus on account of their "invisibility" in the target culture. Both translations were not reedited and are indeed no longer available in the target culture. This does not mean that those translations are not worth studying. Further research is needed to determine why they did not meet with the same success as the other translations of the work. Is it a coincidence that the only two translations produced by women did not prove to be successful in the long run?
} 
Internet. They are to the first two and the last two translations that were made of the work: Émile de La Bédollière's translation (published in 1850 by G. Barba ), Alfred Gérardin's (published in 1858 by Hachette), Sylvère Monod's (published in 1957 by Garnier Frères) and Francis Ledoux's (published in 1958 by Gallimard).

Polysystem theory will help map out the journey of Oliver Twist in(to) the French culture. The first stage of this journey is the point of contact between the source text and the target culture, namely the nineteenth century for Oliver Twist. The work was then introduced into the French literary landscape through (re)translation. At this stage, it is shaped by the translating culture or "dismembered". Then the work gradually moved from the periphery to the centre of the polysytem. It was both re-memembered and dis-membered in the process since the second stage of the journey is defined by both the retranslation and the adaptation of the work. In the case of Oliver Twist, the journey continued with the academic retranslations of the work in the twentieth century and has gone on with the various adaptations of the work to this day.

\section{Making Memories through "Dis-memberment"? Entering the System of National Literature through $(\mathrm{Re})$ translation in the Nineteenth Century}

Within the general framework of the polysystem, the first step leading to remembering the literary legacy of another culture is to welcome their literary works. One way of doing so is by importing their works through translation. The works selected in this process by the target culture supposedly bring something new to the literary system of the receiving culture:

It is clear that the very principles of selecting the works to be translated are determined by the situation governing the (home) polysystem: the texts are chosen according to their compatibility with the new approaches and the supposedly innovatory role they may assume within the target literature. (Even-Zohar 47, my emphasis)

As underlined in the introduction, depending on its position in the polysystem, the newly introduced work can either shape polysystem or be shaped by it. In the first half of the nineteenth century, the second case applied. At the time, remembering generally implied naturalizing or domesticating the foreign work: "[...] the translations visibly worked within what was called 'French' literature and the various key options available to the translators were derived from the guiding principles shaping the literary production of the time" ${ }^{\prime 8}$ (Lambert 1, mt). To rephrase this in light of polysystem theory,

\footnotetext{
${ }^{7}$ Note that Émile de la Bédollière's translation, entitled Les voleurs de Londres and published in 1850 by G. Barba, is similar to the translation produced in 1841 by a certain Ludovic Bénard, supposedly at the time a pen name for Émile de La Bédollière (Monod, "Les premiers traducteurs de Dickens" 121). The 1841 translation was also published by G. Barba and the title was Olivier Twist, ou l'orphelin du dépôt de mendicité. It was reedited in 1878 by E. Ardant. La Bedollière's translation would therefore be the very first translation of the work into French.

8 «A cette époque [1800-1850], les traductions fonctionnent manifestement à l'intérieur de la littérature dite "française" et différentes options essentielles des traducteurs sont orientées par les lignes de force de la literature du moment » (source text). From now on "my translation" will be abridged into "mt".
} 
translated texts were at the periphery of the literary system and thus subject to the norms of the target system:

$[\ldots]$ when translated literature occupies a peripheral position, ... the translator's main effort is to concentrate upon finding the best ready-made secondary models for the foreign text, and the result often turns out to be a non-adequate translation [...] (Even-Zohar 50)

Of that, Oliver Twist is a case in point.

The journey of Oliver Twist in French culture began in the nineteenth century through its translation and retranslation into French. At the time the translation of Dickens' work did play an innovatory role within the target literature because fiction was very much anchored in the classical standards set by Walter Scott. Dickens was translated at a time when realism was gaining ground in the national literature, at the expense of what were then considered more noble forms of literature, such as historical novels or poetry. The first half of the nineteenth century saw the rise of the popular novel and the social novel in France (Delattre 93). According to Delattre, Dickens' work responded to a need in the French literary landscape that he identified as a mix of realism and romanticism, or "that newly-felt need, that impulse towards the middle of the century in France in which the French translations were themselves caught up, as it were" (97). ' In a word, the newly introduced work by Dickens in translation was part and parcel of the regeneration of the national literature.

In Oliver Twist, in particular, social realism takes the form of the juxtaposition of tragic and comic scenes. In Dickens' eyes, that was the stuff reality was made of ${ }^{10}$. Therefore, while the novel gives a realistic portrayal of London's criminal underworld, it also includes grotesque ${ }^{11}$ passages that are rooted in the two Dickensian idiosyncracies of animation and reification. Those are present in both the characters' and the narrator's utterances. They rely partly on figures of speech such as similes $^{12}$ (Tomita), metaphors ${ }^{13}$, syllepses ${ }^{14}$ or hypallages $^{15}$ (Tarif). This non-differentiation between

\footnotetext{
9 «[...] ce besoin nouveau, cet appel d'air qui se produisit en France vers le milieu du siècle dernier, et dans lequel les traductions françaises de Dickens furent elles-mêmes comme entraînées » (Delattre 97).

${ }^{10}$ In the novel, Dickens uses the metaphor of the colours of a piece of bacon to refer to life being essentially an alternation of tragedy and comedy: "It is the custom on the stage, in all good, murderous melodramas, to present the tragic and comic scenes in as regular alternation as the layers of red and white in a side of streaky, well-cured bacon [...] Such changes appear absurd; but they are by no means unnatural" (117).

${ }^{11}$ As underlined by Isabelle Hervouet-Farrar in her introduction to The Grotesque in the Fiction of Charles Dickens and Other $19^{\text {th }}$-century European Novelists, the grotesque is a notion full of nuances. One unifying idea she highlights is nevertheless the "fusion of heterogeneous elements" (1). One central idea is also that in the grotesque "the realm of inanimate things is no longer separated from those of plants, animals, and humans" (Kayser in Hervouet-Farrar 2). Further, in Dickensian works one can find elements falling under the two traditional categories of the grotesque, "the comic and burlesque" and "the abnormal and the horrible" (Hervouet-Farrar 2).

${ }^{12}$ In the following simile there is, for instance, an analogy between the spectacles of the protagonist and part of her face: "The old lady made no reply to this; but wiping her eyes first, and her spectacles, which lay on the counterpane, afterwards, as if they were part and parcel of those features, brought some cool stuff for Oliver to drink [...]" (82, my emphasis). The simile gives the idea that the spectacles are alive and that the face of the protagonist is not.
} 
the human and the non-human is "a longstanding truism of Dickensian stylistics" (Stewart 141) and is therefore key in translation. Those linguistic eccentricities accounted for critics such as Trollope's: “Of Dickens' style, it is impossible to speak in praise. It is jerky, ungrammatical, and created by himself in defiance of rules" (208).

The paratexts of the first two translations are clearly designed to help Dickens' work enter the new culture and put forth the innovatory quality of his work. It does so in two different ways. The biographical note that G. Barba added to its 1841 edition of the work in French insists on the uniqueness of the writer who, it says, "is far from having the popularity he should have here" (1, $\mathrm{mt})^{16}$ and "has no exact equivalent among French writers" (12, mt). ${ }^{17}$ This edition also features the translator's annotations as footnotes throughout the work. Those are designed to shed light on the cultural complexities of the source text for the target readership ${ }^{18}$. There is no such biographical introduction in the 1858 Hachette translation, but in that new French edition of Oliver Twist Dickens addresses himself to the French public in a preface that did not exist in the original text. This preface gives value to the newly-introduced translation of his work by highlighting its uniqueness:

The present translation of my writings was proposed to me by Messrs. L. Hachette and Co. and Ch. Lahure in a manner equally spirited, liberal, and generous. It has been made with the greatest care, and its many difficulties have been combated with unusual skill, intelligence and perseverance. It has been superintended, above all, by an accomplished gentleman, perfectly acquainted with both languages, and able, with a rare felicity, to be perfectly faithful to the English text, while rendering it in elegant and expressive French. This is the only edition of my writings that has my sanction. I humbly and respectfully, but with full confidence, recommend it to my French readers. (vii-viii, my emphasis)

And yet, the "faithfulness" of Gérardin's translation to the source text, just as La Bédollière's, proves to be somewhat limited (Vanfasse 139). It is true nevertheless that the Hachette translation

\footnotetext{
13 Typically, Dickensian houses or buildings seem to have a life of their own, as in the following extract: "The old smoke-stained storehouses on either side, rose heavy and dull from the dense mass of roofs and gables, and frowned sternly upon water too black to reflect even their lumbering shapes" (chap. XLVI, my emphasis).

14 "A construction in which one word (usually a verb or preposition) is applied to two other words or phrases, either ungrammatically or in two differing senses [...] (often an abstract sense and a concrete sense) [...]" (Baldick 112). For instance, in the following sentence the two nouns that are coordinated have respectively a concrete and an abstract meaning: "[...] the members of the board having resumed their seat and their solemnity [...]" (31, my emphasis).

15 An hypallage is defined as "A figure of speech by which an epithet is transferred from the more appropriate to the less appropriate of two nouns [...]" (Baldick 57). For instance, qualitative adjectives that are usually used to describe a behaviour are used instead to qualify a thing, as in the following examples: "[...] a most malicious cough from Mr. Grimwig determined him that he should [go out]" (102, my emphasis); "Mr. Dawkins gave his hat a ferocious cock $[\ldots]^{\prime \prime}(127$, my emphasis).

16 « [...] qui est loin d'avoir chez nous la célébrité qu’il mérite » (source text).

17 «Dickens n'a point d'analogue exact parmi les littérateurs français » (source text).

18 The following footnote appearing at the beginning of the translation is a case in point: "The beadle oversees the parish workhouse. His attire and functions have nothing in common with those of our French beadles" (15, mt). "Le bedeau est un homme chargé de la police intérieure des dépôts de mendicité. Son costume et ses fonctions n'ont rien de commun avec ceux de nos bedeaux en France » (source text).
}

This work is licensed under a Creative Commons Attribution 3.0 License 
of the work was instrumental in popularizing Oliver Twist and Dickens' work in general on account of its many reeditions (Vanfasse 139).

In the two nineteenth-century translations, Oliver Twist underwent certain "adjustments". 19 The liberties taken by the translators with the original work show that operational norms were operative in the translating culture. More specifically, matricial norms ${ }^{20}$ and textual-linguistic norms ${ }^{21}$ informed the translation decisions of $\mathrm{La}$ Bédollière and Gérardin. For instance, the very first translation by La Bédollière was shorter than the source text. There were quite a few deletions ${ }^{22}$ at the sentence and paragraph levels: some words or sentences were not translated. That may be in keeping with the fact that "the length of his [Dickens'] works [...] was often not pleasing to [the French]" (Devonshire 16). In terms of style, many Dickensian "grotesqueries", including the two Dickensian idiosyncracies of animation and reification present in the narrator's discourse, were not reproduced in the two nineteenth-century translations, resulting in the minimizing of the grotesque in both works. The reason for that is nonetheless different in both cases: in La Bédollière's translation, many descriptive passages, some of them containing grotesque occurrences, are suppressed, while in Gérardin's, the grotesque occurrences are purposefully suppressed by the translator. $^{23}$

These translation strategies may very well be the result of the literary tastes prevailing at the time. The "lasting popularity of Walter Scott's novels of romance and chivalry" (Vanfasse 138) can explain the mixed reception of Dickens' work in France then: on the one hand it was acclaimed by readers, and on the other hand it was disparaged in terms of its language and characterization by literary critics (Delattre 53). Minimizing the grotesque in the narrator's discourse was a way of ensuring the compatibility of the translations with a more traditional vision of realism. Incidentally,

\footnotetext{
${ }^{19}$ Note that Gérardin's translation was published in the second half of the century, in 1858, but that Lambert's comment about the tendency to domesticate translations in the first half of the century applies to Gérardin's work.

20 " [...] matricial norms may govern the very existence of target-language material intended as a substitute for the corresponding source-language material (and hence the degree of fullness of translation), its location in the text (or the form of actual distribution), as well as the textual segmentation. The extent to which omissions, additions, changes of location and manipulations of segmentation are referred to in the translated texts (or around them) may also be determined by norms, even though the one can very well occur without the other" (Toury 58-59).

21 "[...] govern the selection of material to formulate the target text in, or replace the original textual and linguistic material with" (Toury 58)

22 The term "deletion" is preferred in this article over the term "omission" on account of the latter's negative connotations. It is indeed defined as "A translation error where the translator fails to render a necessary element of information from the source text into the target text." (Delisle et al. 165) The term is borrowed from Maria Tenchea, who uses the word "effacement" in French. She defines "effacement" as: "The elimination in the target text of one or several elements that were present in the source text" $(120, \mathrm{mt})$. This definition has the advantage of being objective. It leaves room for interpretation as it does not take into account the potential motivation and constraints accounting for the choice of the translator.

${ }^{23}$ For example, the adjective "cheerless" is suppressed in La Bedollière's translation of the animist "cheerless grate" (239) - see the Ardant edition of the work, page 203. Correspondingly, the animist clause "The old smoke-stained storehouses frowned sternly" (305) is not translated, being part of a larger descriptive paragraph suppressed in the translation - see the Ardant edition of the work, page 261.
} 
the introduction to the $1841 \mathrm{G}$. Barba edition highlights the documented nature of the work, along with its realism and historicity (2-4), something Dickens also did in the source text. ${ }^{24}$

Despite the mixed reception of Oliver Twist by the French literary critics in the nineteenth century, Delattre concludes that by the mid-nineteenth century "the name of Dickens and his work had progressively and successfully made their way among us" $(60, \mathrm{mt}) .{ }^{25}$ This translates into the idea that the work was progressively migrating to the centre of the French literary polysystem. The next stage in the journey of the novel towards canonicity took place in the twentieth century with the retranslations of the work at a time when scholarly translations of the work were undertaken.

\section{Twentieth-Century Academic Retranslations, "Re-memberment" and the Making of a Classic}

Literary criticism is a metaliterary activity generating classics (Mukherjee 1027). Retranslation is another such activity (Lefevere in Hermans 125). As mentioned in the introduction, both retranslation and canonicity are mutually dependent, the status of a classic often promoting further retranslations. Bearing that in mind, the notion of performance is particularly fruitful. It was used by Martin, drawing on Coetzee's "What is a Classic?": "Translation is a very intense form of reading and both reading and translation are ways in which a literary work can be performed" (14). Each new translation works as a new reading or a new performance of the source text, all of its translations drawing the readers closer to what the text essentially is: a plurality of meanings. The mosaics of existing translations enact the potentialities of the source text. Each translation projects one particular image of the text, so that "we can never speak of the translation" (McFarlane 89, my emphasis). According to McFarlane, "there will inevitably be different translations deriving from different meanings, all of them perhaps equally valid but none of them an 'ideal' or a 'true' one" (89). Thus, while translation as a decision-making process involves an inevitable entropic movement, retranslation as a dynamic process appears as a productive means of making a more accurate memory of the source text.

Two retranslations or new performances of Oliver Twist were released in the Twentieth century, interestingly enough only one year apart: Monod's translation was published in 1957 and Ledoux's in 1958. This reminds us that the need for a new translation is not necessarily linked to the idea of the ageing of a previous translation and that the status of a classic often calls for further retranslations. Both translations were carried out by two academics who had some knowledge of the nineteenth-century translations of the work. This ties in with Venuti's remark that " $t$ the retranslation may claim to be more adequate to the foreign text in whole or part, which is to say more complete or accurate in representing the text or some specific feature of it" (26). Compared to the nineteenth-century translations, both twentieth-century translations are now part of collections

\footnotetext{
${ }^{24}$ In his 1841 preface of the original text, Dickens insisted on the realistic nature of Oliver Twist as a response to the critics who had found fault with his work: "IT IS TRUE [...] It is emphatically God's truth, for it is the truth" ("Oliver Twist: Authoritative Text" 6-7).

25 « le nom et l'oeuvre de Dickens pénètrent peu à peu et s'installent solidement au milieu de nous » (source text).
} 
that are explicitly advertised as proposing "classics", showing the progress of the work towards the centre of the polysystem. Monod's translation is part of the "Classiques Garnier", by the publisher Garnier Frères, and Ledoux's is part of the Bibliothèque de La Pléiade ${ }^{26}$, by Gallimard. The very close temporal proximity of the publications raises the question of their own specificities in relation to the source text: How is the source text remembered in each? Or, in other words, drawing on Coetzee's notion of "performance", what types of performances of the source text do the retranslations offer, compared to the previous two nineteenth-century translations? And to carry the analogy further, given that the notion of performance is closely related to the idea of a "performer" but also to that of a "stage/staging", what role does the translator (i.e., the "performer") or the collection in which the translation appears (i.e., the "staging") play in the new proposed version?

In the case of the first twentieth-century retranslation of Oliver Twist, one might argue that the name of the translator is more significant than in the second retranslation. While the collection in which the translation was published gave its value to the other twentieth-century retranslation, in the case of the first translation the reputation of the translator gave credit to the translation and added a certain value to it. The reason is that Monod was a French scholar who was known at the time as "the" French Dickensian (Sadrin 105). Just a few years before the publication of the translation, in 1953, he had completed his Doctoral Dissertation, entitled Dickens Romancier. The dissertation examined the evolution of Dickens' style through his novels. It obtained international recognition, was translated into English as Dickens the Novelist and was published in 1968 by the University of Oklahoma Press. The "French Dickensian" was therefore the author of the Garnier Frères translation but he also wrote an introduction, provided notes and a bibliography.

In the case of the second twentieth-century translation, the name of the collection gives its value to the work. It was published by Gallimard in its prestigious collection "La Bibliothèque de La Pléiade". It was really significant in terms of the work's progress in the literary system. Dickens had entered the collection a few years before, in 1954, with the translation of David Copperfield. And in the French literary world, there is no better way "to be remembered" than to be part of this collection, seen as "a great instance of consecration" 27 (Durand para 6, mt). It was very significant for Dickens' work to be published in the "Bibliothèque de La Pléiade": from then on, he was at the very heart of the French literary system. In this collection, national literature and foreign literature are put side by side. The collection had indeed embraced the pivotal change that occurred in the literary system in France in the 1930s, a change that put at its centre translations from languages other than Greek or Latin. The new canon that emerged then included writers such as Shakespeare, Tolstoï, Dostoïevski and Balzac (Gleize 55). This is proof that some works in translation that used to be part of a subsystem or peripheral system migrated to the centre of the literary system.

\footnotetext{
${ }^{26}$ The webpage dedicated to the collection features an old advertisement promoting the "Bibliothèque de La Pléiade" dating back to the 1930s. It reads "La Fontaine, Beaudelaire, Montaigne, Cervantes, Rousseau, Stendhal, Voltaire, Rabelais, Molière, Musset, Laclos, Racine, Poe, Corneille, La Rochefoucault, La Bruyère, Mérimée, Beaumarchais, Diderot, etc...", "All the classics on one shelf only" (La collection Bibliothèque de la Pléiade, mt).

27 « une grande instance de consécration » (source text).
} 
The "stagings" of the two twentieth-century retranslations are yet paradoxically similar. Both translations were completed at a time when Dickensian Studies had become somewhat of a "science" (Sadrin 102) ${ }^{28}$. As underlined by Sadrin, the first half of the twentieth century saw the publication of major works about Dickens, both informative and interpretative (103). Thus both scholars Monod and Ledoux benefited from new insight into the writer's world and writing. It was also a time when a new approach was adopted in translation. Back then, scholarly standards gave pride of place to a certain precision and meticulousness in translation (Vanfasse 139; Delattre 51-52). Hence the similar stylistic performances of the two translators: they produced versions of the original work that are more literal and respectful of the integrity of the text than the nineteenthcentury translations. Therefore, in the second stage of the journey of Oliver Twist to canonicity, "dismemberment" gave way to "re-memberment". But that movement was also simultaneously accompanied by the metamorphoses of the translated work once it had achieved the status of the classic, another form of dis-memberment.

\section{Staying Alive in our Memories? The Metamorphoses of a Classic}

The notion of inexhaustibility is key to understanding how a classic stays alive in the cultural memory of the translating culture. The term was originally used by Calvino to refer to one defining feature of a classic, in the sense that a classic in his opinion needs to be read over and over again (Calvino qtd in Martin 8). The term is to be understood more globally here in relation to the translation of a classic: the "inexhaustibility" of the classic translates either into the retranslation of the work or its adaptation within the literary system or into another cultural system. The adaptation of the original work into other media and genres allows it to speak to a plurality of audiences, as its various literary "rewritings" help a wider audience remember it longer.

The inexhaustibility of the classic is manifest in the filmic system. That inexhaustibility takes either the form of the cinematographic adaptation of the work in the target culture or of the subtitling/dubbing of an adaptation in English of the original work. The cinematographic medium and its different genres appear to be the first logical step to the adaptation of a foreign classic. Oliver Twist was the first Dickens' book to be used to make a film (Pointer 21). Several silent versions of the book were produced in France, including Oliver Twist by Gaumont (1906) or L'enfance d'Oliver Twist (1910) by André Calmettes and Camille de Morlhon (1910). The famous 1922 Hollywood silent adaptation by Frank Lloyd reached the screen the same year in the United States and France ${ }^{29}$. There were other more modern adaptations of the book in French: for instance, a two-episode series by Jean-Paul Carrère (1962) or, more recently, a film by Roman Polanski (2005). Numerous cinematographic adaptations of the book in English were subtitled and/or dubbed into French for

\footnotetext{
28 "Then suddenly everything changed. Specialists took an interest in the question, literary criticism became a science and Dickens made his way into our universities" (mt). «Puis, brusquement, tout changea. Les spécialistes s'en mêlèrent, la critique devint une science et Dickens entra à l'Université » (source text).

${ }^{29}$ Subtitling techniques were developed during the silent era to ensure the financial viability of the first Hollywood pictures in other countries, France being one of the markets coveted by Hollywood then (Cornu).
} 
the French market, including William J. Cowen's 1933 version and David Lean's famous 1948 $\operatorname{adaptation}^{30}$.

Oliver Twist was also adapted into the musical genre. Carol Reed's musical film, Oliver!, was released in France in 1968, a few months after it was released in the United States. More recently, it should be mentioned that the work was adapted by Christopher Delarue and Shay Alon into a French musical in the anglo-saxon tradition. Oliver Twist, le Musical, will be premiered in Paris in September of 2016. As an ultimate metamorphosis of the original work in the filmic system, the classic is turned into an animated film targeting a younger audience: the animated film Oliver \& Company by Walt Disney Studios was released in France as Oliver et Compagnie in 1989. The animated film inspired a fifty-two episode animated series entitled Saban's Adventures of Oliver Twist broadcast in France as Les nowvelles aventures d'Oliver Twist in 1997-1998.

Within the literary system per se, there seems to be a natural diachronic route for the media that the classic is adapted into and thus remembered. As it is the case in the filmic system, a classic not only calls for the retranslation of the work for an adult audience but also for its adaptation into other literary media accessible to a larger readership. The original work is therefore generally adapted into a children's book: the classic is made available to a younger audience in an abridged version. Oliver Twist has been adapted for a young audience by several French publishers: for instance, by Éditions Hemma (1969), Hachette Jeunesse (2005), L'école des loisirs (2005) or Nathan (2006). The collection more often than not advertises the text as a "classic". L'école des loisirs, for example, published Oliver Twist in its collection "Classiques abrégés" and Hachette, in "Le livre de poche classique".

The journey of a classic into the literary system also implies its metamorphosis into a graphic text. Adaptations of literary classics into comic books, in one or several volumes, have become very popular over the last ten years in France (Tohmé), so much so that it seems that the transposition of a foreign classic into that medium is now part of the natural "progression" of the work into the translating culture. The intended audience is in that case more diverse than for a translation since comic books target both youths and adults. Again, as in the case of retranslations for adults or for children, those works are generally included in special collections that advertise more or less explicitly that the book is a classic. One of the first adaptations ${ }^{31}$ of Oliver Twist into a comic book was a co-edition published by Éditions Ytra - Télé-Guide in 1978. It is part of a series of eleven adapted classics. ${ }^{32}$ The last adaptation of the original work to date was undertaken by the publisher

\footnotetext{
30 TCM specifies that Cowen's version was dubbed into French the same year it was released in the United States. In the case of David Lean's Oliver Twist, further research would be needed to determine if the movie was first released in France with French subtitles and only later as a dubbed version into French, which was not uncommon before World War II (Cornu). In any case, the film was released in France the same year it was released in the UK.

31 The very first adaptation of the work into a graphic format appeared in an issue of Tintin dedicated to Charles Dickens in 1970. The issue featured a six-page long adaptation of the book by Uralde and Duval.

32 The collection is made up of the following eleven classic titles published between 1976 and 1985: Aladin (1976), Le Petit Poucet (1978), Oliver Twist (1978), Pinocchio (1978), Tom Sawyer, (1978), Un conte de Noël (1978), Ali-Baba et les quarante voleurs (1978), Voyage au centre de la Terre (1980), Les voyages de Gulliver (1985), Robin des bois (1985), Robinson Crusoé (1985).
} 
Delcourt. Oliver Twist is part of Ex Libris, a collection in which the literary classics are said to find a new life as comic books. The format of the publication may vary in terms of the number of published volumes: the original work can indeed appear as a series as it originally was. Delcourt, for instance, published Oliver Twist in five volumes, which is reminiscent of the serialization of the original work, something common in the nineteenth century. The first volume was released in 2007 and the last in 2011, just before the celebration of the $200^{\text {th }}$ celebration of Charles Dickens' birth. One last metamorphosis of the source text known as "extrapolation" relies on the exploitation of one of the characters of the original work who "is plucked from his or her literary context and placed in a new situation [...]" (Grossman 489). It is the case for Fagin the Jew by Will Eisner, translated into French as Fagin le juif. The comic book challenges the stereotyped depiction of Fagin offered in the original work by Dickens. In his work, Eisner rehabilitates the figure of the Jew.

Be they the result of mimesis or extrapolation, all the adaptations mentioned above were inspired directly by the original work. Those works shape the cultural body of the translating culture as it directly inspires other authors in the translating culture, and by authors I mean translators and adapters. But the original work in translation can also indirectly shape the literary system of the translating culture. Dickens' Oliver Twist has for instance worked as an intertext in different French texts, be it acknowledged by its author or not. Take for instance Alphonse Daudet's Le Nabab and the characters of Mme Polge and M. Pondevez, who are reminiscent of Oliver Twist's Mrs. Mann and the Beadle (Johnson 28-29); or Jules Verne, who admired Dickens's work and paid tribute to Oliver Twist in his novel P'tit-Bonhomme (Dekiss qtd in Soubigou).

More generally, intersystemic relations help a work stay alive in the target culture's literary memory. Other systems can generate literary retranslations. It was the case, for example, for the already mentioned 2005 cinematographic adaptation of Oliver Twist by Polanski: a new translation of the book for children by Michel Laporte was published shortly after the book was released by Hachette Jeunesse, with a book cover matching the movie poster, presumably to help selling the book. Another more indirect intersystemic relation lies in the interest that may grow out of an adaptation of the original work in the translating culture. Grossman mentions the interest a filmic adaptation can generate for the original work in translation, something she identifies as "a pre-text" (492). But generally speaking, any translation can play this role. Reading a comic book adaptation of the work can trigger a need for (re)reading the original book, as suggested by one review of Eisner's Fagin le juif: "Beware of the irrepressible urge to re(read) Dickens, once you've finished reading Eisner's 122 pages” (Fomperie, $\mathrm{mt}$ ).

By reaching a wider readership, the text settles in the translating culture's memory. But the popularization of the sphinx-like classic paradoxically entails an entropic movement: part of the work dies with its rebirths. The question was raised by Grossman about Victor Hugo's Le bossu de Notre-Dame (The Hunchback of Notre Dame). The trajectory of the work is similar to Oliver Twist's, as it was retranslated and adapted into English in different media several times. Both source texts were dis-membered in the sense that they were adapted to the format of the target product and the age of 
its public. This means for Oliver Twist that, for instance, the sub-plots that are an important part of the realism of Dickens' stories cannot all appear in the adaptations; correspondingly, the voice of the narrator that accounts for much of the grotesque of Dickens' work and is so important to its comedy is absent from the adapted target works.

The durability of Oliver Twist in the French literary system under several genres and formats is symptomatic of the significance of the work in the French cultural landscape, including its literary landscape. The historicity of the story, which represents a piece of Victorian History, is one reason for its lasting influence. The work has become a symbol in the translating culture: "Daily newspapers nowadays frequently mention Oliver Twist as an English version of Hugo's Gavroche in Les Misérables" (141). The conclusion Grossman draws for Hugo's Le bossu de Notre-Dame is relevant to Dickens' Oliver Twist. "The literary text has been supplanted by a mythical, timeless plot - a parable of oppression" (Grossman 487). And the characters have become "archetypal" (487) and "transhistorical" (487). The relevance of Oliver Twist in today's society is also highlighted in the online presentation of Oliver Twist, le musical. The presentation of the show insists on the idea that, surprisingly enough, the world depicted in Dickens' work mirrors the world we currently live in. This is in a nutshell what this classic is remembered as: not only as a depiction of the nineteenthcentury London underworld but more generally as a representation of the harshness of today's society.

\section{Conclusion}

The journey of a work into another culture begins with its translation into the language of that culture, a process symptomatic of a need to be filled in the literary system of the translating culture. The work progressively acquires its status as a classic through its rewritings and metamorphoses in the translating culture, the different cultural systems feeding one another in the process. The resulting mosaic of translations, be they the result of a translation or of an adaptation to cater to different audiences, regenerate the source text as much as the translating culture as they reveal the work under a different light each time. The fact that the work inspires other authors is a sign that (re)translation shapes the literary system of the translating culture or its cultural system as a whole. But the inexhaustibility of a classic, so essential to its survival, also poses the question of the dilution of the original. The status of a classic also means for it to dissolve into something that loses part of the original. An extreme manifestation of this dilution is the commodification of classics. For instance, the adaptation of a classic such as Oliver Twist into a Disney animated film goes hand in hand with the sale of knickknacks, such as soft toys. This is one aspect to be added to this multifaceted notion of a classic, an aspect that also leads to the remembrance of the work in the long run. 
TranscUlturAl, vol. 8.1 (2016), 38-56.

http://ejournals.library.ualberta.ca/index.php/TC

\section{REFERENCES}

\section{Primary Sources}

Delarue, Christopher and Shay Alon. Oliver Twist, le Musical. N.p. N.d. Web. 25 December 2015.

Dickens, Charles. Les papiers posthumes du Pickwick Club; Les aventures d'Olivier Twist. Trans. Sylvère Monod and Francis Ledoux. Paris: Gallimard, 1958. Print.

. Oliver Twist. Trans. George Gibson. Paris: Nathan, 2006. Print.

. Oliver Twist. Dir. Roman Polanski. Perf. Barney Clark and Ben Kingsley. TriStar Pictures, 2005. Film.

—. Oliver Twist. Trans. and adapt. Michel Laporte. Paris: Hachette Jeunesse, 2005. Print.

- Oliver Twist. Trans. Charlotte Pressoir and Marie-Louise Pressoir. Adap. Marie-Hélène Sabard. Paris: L'École Des Loisirs, 2005. Print.

Oliver Twist: Authoritative Text, Backgrounds and Sources, Early Reviews, Criticism. Ed. Fred Kaplan. New York: W.W. Norton, 1993. Print.

—. Oliver Twist. Adapt. Yves Duval and Uralde. Tintin 1140 (1970): 14-19. Print.

- Oliver! Dir. Carol Reed. Perf. Mark Lester and Ron Moody. 1968. Columbia Pictures. Film.

- Oliver Twist. Dir. Jean-Paul Carrère. Perf. Gérard Riou, André Oumansky, Alice Reichen and René Clermont. ORTF, 1962. Film.

—. Oliver Twist. Trans. Sylvère Monod. Paris: Garnier Frères, 1957. Print.

—. Oliver Twist. Dir. David Lean. Perf. John Howard Davies and Robert Newton. Rank Organisation, 1948. Film.

- Oliver Twist. Dir. William J. Cowen. Perf. Irving Pichel, Dickie Moore, Doris Lloyd and William Boyd. Monogram Pictures, 1933. Film.

- Oliver Twist. Dir. Frank Lloyd. Perf. Jackie Coogan and Lon Chaney. Associated First National Pictures, 1922. Film.

- Oliver Twist. 1906. Gaumont. Film. 
—. Oliver \& Company. Voiced by George Scribner. Joey Lawrence, Billy Joel, Natalie Gregory. Walt Disney Pictures. 1988. Film.

—. Oliver \& Compagnie. Voiced by Renaud, Tissier, Billy Joël, Natalie Gregory, Cheech Marin. Walt Disney Pictures. 1988. Film.

—. Olivier Twist. Trans. and adapt. Henri Monnier. Paris: Éditions Hemma, 1969. Print.

—. Olivier Twist. Trans. Madeleine Bouygues. Paris: Éditions Athêna, 1953. Print.

—. Olivier Twist. Trans. Jeanne Dulong. Paris: Éditions du dauphin, 1948. Print.

- Olivier Twist, les voleurs de Londres. Trans. Émile de La Bédollière. Limoges: E. Ardant, 1878. BnF Gallica. 11 Janv. 2010. Web. 31 December 2015.

- Olivier Twist. Trans. Alfred Gérardin. Paris: Ch. Lahure et $C^{\mathrm{ie}} .1858$ [1867]. Google Books. Web. 31 December 2015.

- Olivier Twist, les voleurs de Londres. Trans. Émile de La Bédollière. Paris: G. Barba, 1850. BnF Gallica. 11 Janv. 2010. Web. 31 December 2015.

- Olivier Twist, ou l'orphelin du dépôt de mendicité, vol. 1-4. Trans. Ludovic Bénard. Paris: G. Barba, 1841. BnF Gallica. 6 Nov. 2012. Web. 31 December 2015.

- Souvenirs intimes de David Copperfield; De grandes espérances. Trans. Pierre Leyris, Lucien Guitard, André Parreaux and Madeleine Rossel. Paris: Gallimard, 1954. Print.

Eisner, Will. Fagin the Jew. New York: Doubleday, 2003. Print

—. Fagin le juif. Trans. Anne Capuron. Paris: Delcourt, 2004. Print.

L'enfance d'Oliver Twist. Dir. André Calmettes and Camille Morlhon. Perf. Madeleine Guitty, Marie Dornay, Jean Périer and Renée Pré. 1910. Film d’Art. Film.

Les nouvelles aventures d'Oliver Twist. Dir. Bruno Bianchi. Voiced by Bernard Tiphaine, Natache Gerritsen, Dolly Vanden and Michel Lasorne. Saban International. Salut les Toons TF1. Sept. 1997- Feb. 1998. Television.

“Les nouvelles aventures d'Oliver Twist.” Planète Jeunesse. N.p. N.d. Web. 18 December 2015.

“Les nouvelles aventures d'Oliver Twist.” Anime Guides. N.p. N.d. Web. 18 December 2015. 
Saban's Adventures of Oliver Twist. Dir. Bruno Bianchi. Voiced by Mona Marshall, Tony Pope, Brianne Siddall and Barbara Goodson. Saban Entertainment. Fox Family Channel. Sept. 1996 - Sept. 1997. Television.

\section{Secondary Sources}

Baldick, Chris. The Oxford Dictionary of Literary Terms. Oxford: Oxford University Press. 2008. Print.

Bloom, Harold. The Western Canon: The Books and School of the Ages. New York: Riverhead, 1994. Print.

Carlos A., Cornejo (writer). Fuente, Chiqui (De La) (penciller and inker). Aladin et la lampe merveilleuse. Neuilly-sur-seine: Éditions Ytra - Éditions Télé-Guide, 1976. Print.

—. Le petit poucet. Olivet: M.C.L. Éditions, 1978. Print.

—. Oliver Twist. Neuilly-sur-seine: Éditions Ytra - Éditions Télé-Guide, 1978. Print.

—. Oliver Twist. Willowdale: Presse-Import Léo Brunelle, 1978. Print.

—. Pinocchio. Neuilly-sur-seine: Éditions Ytra - Éditions Télé-Guide, 1978. Print.

—. Tom Sanyer. Neuilly-sur-seine: Éditions Ytra - Éditions Télé-Guide, 1978. Print.

—. Un conte de Noël. Neuilly-sur-seine: Éditions Ytra - Éditions Télé-Guide, 1978. Print.

—. Ali-Baba et les quarante voleurs. Neuilly-sur-seine: Éditions Ytra - Éditions Télé-Guide, 1978. Print.

—. Voyage au centre de la Terre. Neuilly-sur-seine: Éditions Ytra - Éditions Télé-Guide, 1980. Print.

Carlos R., Soria (writer). Fuente, Chiqui (De La) (penciller and inker). Les voyages de Gulliver. Neuillysur-seine: Éditions Ytra - Éditions Télé-Guide, 1985. Print.

—. Robin des bois. Neuilly-sur-seine: Éditions Ytra - Éditions Télé-Guide, 1985. Print. . Robinson Crusoé. Neuilly-sur-seine: Éditions Ytra - Éditions Télé-Guide, 1985. Print.

“Collection Ex-Libris.” Delcourt. N.p. N.d. Web. 29 December 2015. 
Cornu, Jean-François. "Re: Subtitling and Dubbing.” Personal Communication. 29 December 2015. E-mail.

Dauvillier, Loïc (writer). Deloye, Olivier (penciller). Rouger, Jean-Jacques and Merlet, Isabelle (inker). Oliver Twist \#1-5. Paris: Delcourt, 2007.

Delattre, Floris. Dickens et la France; Étude d'une interaction littéraire anglo-française. Paris: Libraririe Universitaire, J. Gamber, 1927. Print.

Delisle, Jean et al. Terminologie de la traduction. Amsterdam: John Benjamins, 1999. Print.

Devonshire, Marian Gladys. The English Novel in France, 1830-1870. London: University of London Press, 1929. Print.

Dickens, Charles. “Oliver Twist.” Turner Classic Movies. N.p. N.d. Web. 25 December 2015.

Durand, Pascal. "La 'Bibliothèque de la Pléiade' : un bon objet." COnTEXTES: Revue de Sociologie de la Littérature (2011): Web. 30 November 2015.

Even-Zohar, Itamar. "Polysystem Studies.” Poetics Today 11.1 (1990): 1-268. Print.

Ezell, Margaret J. M. "Making a Classic: The Advent of the Literary Series.” South Central Review 11.2 (1994), 2-16. Print.

Fomperie Joël “Fagin le juif.” État critique. N.p. 26 July 2009. Web. 18 December 2015.

Gleize, Joe. La Bibliothèque de la Pléiade: travail éditorial et valeur littéraire. Paris: Éditions des archives contemporaines, 2009. Print.

Grossman, Kathryn M. "Classic to Pop Icon: Popularizing Hugo." The French Review 74.3 (Feb., 2001): 482-495. Print.

Hermans, Theo. Translation in Systems: Descriptive and System-Oriented Approaches Explained. Manchester: St. Jerome Publishing, 1999. Print.

Hervouet-Farrar, Isabelle. The Grotesque in the Fiction of Charles Dickens and Other $19^{\text {th }}$-century European Novelists. Newcastle-upon-Tyne: Cambridge Scholars Publishing, 2014. Print.

Jakobson, Roman. "On Linguistic Aspects of Translation.” On Translation. Ed. R. A. Brower. Cambridge, MA: Harvard University Press, 1959. 232-239. Print. 
Johnson, Mabel Clare. The Nature of the Influence of Dickens on Daudet. MA Thesis. University of Illinois Urbana-Champaign, 1908. Web. 12 June 2016.

Koskinen, Kaisa and Outi Palopski. "Retranslation." Handbook of Translation Studies: Volume 1. Ed. Yves Gambier and Luc van Doorslaer. Amsterdam and Philadelphia: John Benjamins Publishing, 2010. 294-298. Print.

“La collection Bibliothèque de la Pléiade.” La Pléiade. N.p. N.d. Web. 20 December 2015.

Lambert, José. "Théorie de la littérature et théorie de la traduction en France (1800-1850): interprétées à partir de la théorie du polysystème." Poetics Today 2.4 (Summer - Autumn 1981): 161-170. Print.

Martin, Charles. "Confessions of a Retranslator." The Hopkins Review 4.4 (Fall 2011): 501-513. Print.

McFarlane, John. "Modes of Translation.” The Durham University Journal 45.3 (1953), 77-93. Print.

Monod, Sylvère. "Les premiers traducteurs français de Dickens.” Romantisme 29.106 (1999): 119-128. Print.

—. Dickens the Novelist. Norman: University of Oklahoma, 1968. Print.

—. Dickens Romancier. Paris: Hachette, 1953. Print.

Mukherjee, Ankhi. “What Is a Classic?' International Literary Criticism and the Classic Question." PMLA 125.4 (2010): 1026-1042.

Palumbo, Giuseppe. Key Terms in Translation Studies. London and New York: Continuum, c2009. Print.

Pointer, Michael. Charles Dickens on the Screen: The Film, Television, and Video Adaptations. Lanham, Maryland: Scarecrow Press, 1996. Print.

Sadrin, Anny. "La critique dickensienne : aperçu historique et perspectives nouvelles." Romantisme 11.34 (1981): 101-113. Print.

Soubigou, Gilles. "Dickens's Illustrations: France and Other Countries." The Reception of Charles Dickens in Europe. Ed. Michael Hollington. London: Continuum, 2010. 142-154. Print.

Stewart, Garrett. "Dickens and Language." The Cambridge Companion to Charles Dickens (2001): 137151. Print. 
Tarif, Julie. "De l'homogénéisation des associations lexicales créatives dickensiennes: le style dickensien mis à l'épreuve en traduction.” Palimpsestes 26 (2013): 25-43. Print.

Tohmé, Youmna. "Les adaptations des œuvres littéraires classiques en bandes dessinées." La BD francophone 14 (2011): n. pag. Web. 15 September 2015.

Tenchea, Maria. "Explicitation et implicitation dans l'opération traduisante." Traductologie, linguistique et traduction. Arras: APU 2003: 109-126. Print.

Tomita, Saoko. "Similes in Oliver Twist. Humanisation and Dehumanisation." ERA 25.1/2 (2008): 25-42. Web. 8 April 2016.

Toury, Gideon. Descriptive Translation Studies and Beyond. Amsterdam-Philadelphia: John Benjamins, 1995. Print.

Trollope, Anthony. An Autobiography. California: University of California Press, 1947. Print.

Vanfasse, Nathalie. "A Historical Survey of French Criticism and Scholarship regarding Dickens." The Reception of Charles Dickens in Europe. Ed. Michael Hollington. London: Continuum, 2010. 123-142. Print.

Venuti, Lawrence. "Retranslations: The Creation of Value." Translation and Culture. Ed. Katherine M. Faull. Special Issue of Bucknell Review 47.1 (2004): 25-38. Print. 